\title{
IMPERATIVES OF INNOVATION AND INVESTMENT DEVELOPMENT OF THE LIVESTOCK INDUSTRY IN UKRAINE
}

\author{
Sergey Selyutin ${ }^{1}$
}

\begin{abstract}
The purpose of the article. Formation of effective state policy and mechanisms for managing innovative development of the agrarian sector in Ukraine is one of the priority tasks facing the state. In turn, the identification and analysis of factors hindering the implementation of the domestic state policy of innovation development of the agrarian sector is also a very important task. Methodology. In the course of the research general scientific and special methods of research were used, in particular: theoretical generalization, comparison and morphological analysis - in the process of formation of the conceptual-categorical apparatus of the research; Structural-structural-functional analysis - to justify the factors of the formation of the state policy of innovative development of the agrarian sector in Ukraine. Results. It has been established that in order to formulate the state policy of innovation development of the agrarian sector in Ukraine, it is necessary to have a clear idea of the structure of the innovative potential of the agrarian sector, the interrelations between its components, the system and factors that allow the most fully and effectively to implement in practice the opportunities laid down in it. In order to form an effective state policy for innovative development of the agrarian sector, a classification of the factors influencing it is proposed. Practical implications. The need to study the factors influencing the state policy of innovative development of the agrarian sector in Ukraine is primarily due to the substantiation of their content and possible forms of manifestation in the context of developing an effective system of state regulation aimed at activating innovation in the agricultural sector. In turn, the factors influencing the innovative development of the agrarian sector depend on the existing structural features of agrarian production, the level of scientific and educational and technical activities, etc. Value/originality. The proposed classification of factors that influence the formation of the state policy of innovative development of the agrarian sector in Ukraine: on the effectiveness of actions; by the nature of influence; on the structure of the infrastructure; by scale of influence. Based on the knowledge of the factors that significantly determine the dynamics of innovative development of the agrarian sector, it is possible to characterize its parameters and, on this basis, to develop recommendations related to the development of a sustainable economic growth strategy for the innovative development of the agrarian sector and the state as a whole.
\end{abstract}

Key words: animal husbandry branch, agricultural production, innovative development, mechanism, technologies.

JEL Classification: 017,032, Q19

\section{Introduction}

Prospects for qualitative and quantitative growth of the national economy are largely determined by the scale of development of the agricultural sector, including the livestock sector, which is important for building the country's export potential and providing affordable food products. At the same time, the functioning of the livestock industry in Ukraine is characterized by a low level of profitability, inadequate product quality, narrowing of the feed base and its inefficiency, irrational use of non-food raw

Corresponding author:

${ }^{1}$ Chernihiv Polytechnik National University, Ukraine.

E-mail: sergeyS@gmail.com

ORCID: https://orcid.org/0020-0003-8018-8539 materials. All this has led to a slowdown in the development of the livestock industry, the rise in price of its products, the loss of competitive positions in both domestic and foreign markets, reduced investment attractiveness. The main sign of the resumption of the ascending development of the livestock industry is to increase the volume of activity, primarily by expanding the range of products, increasing its competitiveness, the development of new markets. It is possible to solve the outlined tasks under the condition of modernization of production, renewal of fixed 
assets, dissemination of innovative processes in the industry, which, in turn, requires the generation of appropriate investment flows. Given the importance of intensifying innovation and investment development of animal husbandry, the need for further theoretical justification of approaches to qualitative renewal of this industry, improving mechanisms for providing investment resources, finding new forms and methods of transfer of innovative technologies.

\section{Features of regulatory influence of the state}

An important provision of this study is the assertion of the decisive role of state regulation in shaping the prerequisites for innovation and investment development of animal husbandry, which is realized through the purposeful influence of public authorities to achieve such characteristics of its quality transformation through appropriate mechanisms, methods and levers. It is established that a special place in the list of effective forms of state regulation of innovation and investment development should be given to programming, which is proposed to consider from the standpoint of combining available to the state and business different forms, methods and levers to achieve the goals of such development. Solving the problems of innovation and investment development requires the development of an appropriate mechanism, the action of which is aimed at achieving the target version of such development (Shcherbata, 2014).

As the experience of countries with a highly civilized socially oriented market economy shows, a prerequisite for the harmonious combination of economic, social and environmental aspects of social development is, first of all, a rationally organized economic function of the state. Democratic rule of law, as a universal form of social organization, is designed to perform two complex functions: national and socioeconomic. The first is to provide the necessary and sufficient conditions for self-preservation of the ethnic community, the historical homeland of which is the country, the spiritual development of the people who created this state, in its unique national and cultural forms. The second must provide all the diversity of material living conditions of its citizens, including socio-demographic, environmental and scientific and technical (Mytiai, 2014).
Carrying out the reform of management systems, it is necessary to proceed from the fact that agroindustrial production is an objective reality, which is manifested in the production-technological and economic-economic interdependence of agricultural production and other raw materials, agroservice and processing. From the point of view of public interests, expressed by the state in the face of government and administration, the livestock sector of Ukraine is a strategically important sector of the economy, whose main task today is to ensure sustainable food security and increase exports (Malik, 2008).

Given these circumstances, state regulation of the livestock sector should be carried out by a system of vertically and horizontally subordinated bodies, which is an important part of the economic function of the state. Without diminishing the importance of other aspects of reforming management systems (eg, personnel), we will limit ourselves to considering the functional apparatus of state regulation and the requirements for the formation of its organizational structures.

The sphere of state regulation is aimed at the implementation of three consolidated functional groups:

- organization and promotion of innovative development, including ensuring the appropriate qualifications of employees in each industry: vocational and higher education, retraining, STI, etc. (the so-called scientific and technical function);

- planning and economic regulation of the pace and proportions of the industry and national economic complexes exclusively by methods of economic influence: government subsidies, tax benefits, recommendations, especially - marketing assistance, purchase of certain products for state and insurance funds at guaranteed prices, quotas production of certain types of products, taking, if necessary, protective measures to protect the domestic market;

- state control and supervision over the observance by producers of the requirements and rules of the current legislation concerning production in the relevant branches of the national economy, including nature management, nature protection, labor relations, relations of producers with the budget, observance of contractual discipline, restriction and direction of horizontal and vertical integration; quality of consumer goods, etc. (Karasova, 2008). 
In the conditions of gradual development of market relations, managerial actions of organizational, recommendatory and partially guaranteeing nature become a priority. To the functional apparatus of state regulation of the agricultural sector of the economy, taking into account its features, there is a need to include a functional group to promote the social development of rural settlements. A special place in the structure of the economic function of the state has the support and organizational support of business development. Entrepreneurship, as an economic activity organized on the basis of private property and aimed at making a profit, and in the conditions of determining the action of market regulators of production is a necessary and most important social driver of economic development (Cherep, 2014). Entrepreneurship development can occur spontaneously, without the active participation of the state. To do this, it is enough to eliminate direct administrative obstacles and obstacles in its path. However, this process, as world and domestic experience shows, is long and very painful for society. The state is called to direct the process of agribusiness development in civilized forms (Dovhan at all, 2011).

\section{The current state of development of the livestock industry in Ukraine}

The results of the study of quantitative characteristics of the functioning of the livestock industry indicate a tendency to decrease in almost all indicators (Table 1).

Yes, as of 2019, the number of animals has decreased significantly in almost all species. The only exception is poultry, the number of which has increased by 3.5 percent. Milk, eggs and honey are important products of animal origin that form the basis of the population's diet. Milk production decreased by $9 \%$ and amounted to 9663.2 thousand tons at the end of 2019. This was primarily due to a decrease in the number of cattle due to increased costs for its cultivation and maintenance and the deterioration of the structure of the feed base. The crisis did not affect egg production during the analyzed period, which remains stable. Regarding the volume of sales of animals for slaughter, it should be noted that with the exception of poultry, for all other livestock in 2019 there was a negative reduction compared to 2014 (cattle $-4 \%$, age and goats $-1.4 \%$, pigs $7 \%$, horses $-3 \%)$. At the same time, cattle and pigs are sold less than kept. The study of animal

Table 1

Dynamics of the main indicators of the functioning of the livestock industry in Ukraine in 2014-2019

\begin{tabular}{|c|c|c|c|c|c|}
\hline \multirow{2}{*}{ Indicators } & \multicolumn{4}{|c|}{ Years } & \multirow{2}{*}{$\begin{array}{l}\text { Growth rate } \\
2019 / 2014\end{array}$} \\
\hline & 2014 & 2017 & 2018 & 2019 & \\
\hline \multicolumn{6}{|c|}{ Livestock and poultry numbers } \\
\hline Cattle, thousand goals & 3884 & 3530,8 & 3332,9 & 3092 & 79,6 \\
\hline Sheep and goats, thousand heads & 7350,7 & 6109,9 & 6025,3 & 5727,4 & 77,9 \\
\hline Pigs, thousand heads & 1371,1 & 1309,3 & 1268,6 & 1204,5 & 87,8 \\
\hline Horses, thousand goals & 316,8 & 261,5 & 244 & 224,4 & 70,8 \\
\hline Poultry, thousand pieces & 213336 & 204831 & 211654 & 220486 & 103,4 \\
\hline \multicolumn{6}{|c|}{ Sales for slaughter of farm animals, thousand tons } \\
\hline Cattle & 651,9 & 617,3 & 609,9 & 626,4 & 96,1 \\
\hline Sheep and goats & 28,9 & 28,6 & 29,8 & 28,5 & 98,6 \\
\hline Pigs & 1048,2 & 1021,6 & 978,9 & 976,3 & 93,1 \\
\hline Horses & 13,8 & 14 & 14,3 & 13,4 & 97,1 \\
\hline Poultry & 1501,1 & 1561 & 1660,4 & 1825,8 & 121,6 \\
\hline \multicolumn{6}{|c|}{ Production of milk, eggs, wool, honey } \\
\hline Milk of all kinds, thousand tons & 10615,4 & 10280,5 & 10064 & 9663,2 & 91,0 \\
\hline Eggs of all kinds, million pieces & 16782,9 & 15505,8 & 16132 & 16677,5 & 99,4 \\
\hline Wool of all kinds, & 2270 & 1967 & 1908 & 1734 & 76,4 \\
\hline Honey, $\mathrm{t}$ & 63615 & 66231 & 71279 & 69937 & 109,9 \\
\hline \multicolumn{6}{|c|}{ Productivity of farm animals, $\mathrm{kg}$} \\
\hline The average annual milk yield per cow & 4644 & 4820 & 4922 & 4976 & 107,1 \\
\hline $\begin{array}{l}\text { The average annual shearing of wool } \\
\text { from one sheep }\end{array}$ & 2,9 & 2,8 & 2,7 & 2,6 & 89,7 \\
\hline
\end{tabular}

Source: compiled according to the reporting data of the State Statistics Service 
productivity showed its growth, so the milk yield per cow increased by $7 \%$ compared to 2014 . The outlined state of functioning of the livestock industry indicates the need to initiate qualitative changes, as domestic demand for animal products is almost exhausted, and therefore increasing the quantitative indicators of the industry is possible only if entering new markets.

The solution of the problem of increasing the volume of livestock production should be comprehensive, primarily by maintaining a competitive position in the developed markets and entering new ones. All this requires a rethinking of approaches to breeding, keeping animals, organization of production processes. An important area is the production of organic and niche products of animal origin.

There has been some progress in the foreign economic activity of the livestock sector, exports of products during 2014-2019 increased by almost $16 \%$. Animal products are mainly exported to the EU, Iraq, Saudi Arabia, the UAE, Vietnam and Hong Kong. It is important to note that this growth was mainly due to the export of poultry and eggs. The largest exporters of poultry products in Ukraine are Myronivsky Hliboproduct agricultural holding, which generates almost $90 \%$ of Ukrainian exports of such products), Zaporizhzhya Meat Processing Complex LTD, Gubin Poultry Complex, Dniprovsky Complex and Agro-Owen.

The livestock sector, on the one hand, is strategically important for providing the population with high-quality food and employment in rural areas, and on the other hand, is characterized by low levels of profitability and productivity. Therefore, increasing the pace and indicators of its development is impossible without state support (direct and indirect). According to the Government Resolution of February 19, 2020 № 109 "On Amendments to the Resolution of the Cabinet of Ministers of Ukraine of February 8, 2017 № 77" state support for livestock development covers the following areas: subsidies for existing bee colonies (from 10 to 300 bee colonies, in in the amount of 200 hryvnias per bee colony); reimbursement of the cost of purchased breeding animals, bees, sperm and embryos (up to $50 \%$ of the value (excluding value added tax), but not more than the established limits); reimbursement of the cost of livestock facilities (up to $30 \%$ of the value excluding value added tax); compensation of the value of objects financed by bank loans (in the amount of $25 \%$ of the amount of borrowed funds for the crediting period up to 5 years). At the same time, the budget for such state aid is limited and cannot meet all the needs of the livestock industry and provide sufficient conditions for its quantitative and qualitative growth. Thus, the state will allocate UAH 100 million to support the development of animal husbandry in Ukraine in 2021. Also among the problems of providing state support to producers of livestock products are the following: fragmentary implementation of its individual areas; variability and complexity of conditions for receiving state subsidies; lack of effective regional support programs, etc. All this narrows the opportunities for animal producers to qualitatively update production processes, expand the range of goods of animal origin, improve their quality, which, in turn, causes a loss of competitive advantage by such producers and weaken their position in relevant markets.

\section{Strategic vectors of innovation and investment development of the livestock industry in Ukraine}

The study showed a slowdown in the development of the livestock industry, due to reduced demand for animal products, rising costs of doing business, lack of sufficient investment sources for technical and technological modernization of the industry. At the same time, it has a high potential for quantitative and

Table 2

Dynamics indicators of exports and imports of animals and products of animal origin in Ukraine in 2014-2019 (thousand US dollars)

\begin{tabular}{|c|c|c|c|c|c|c|c|c|}
\hline \multirow{2}{*}{ Indexes } & \multicolumn{6}{|c|}{ Years } & \multirow{2}{*}{$\begin{array}{c}\text { \% until } \\
2014\end{array}$} & \multirow{2}{*}{$\begin{array}{c}+/- \text { until } \\
2014\end{array}$} \\
\hline & 2014 & 2015 & 2016 & 2017 & 2018 & 2019 & & \\
\hline Export & 1014474 & 823435 & 775037 & 1108757 & 1211078 & 1170078 & 115,3 & 155604 \\
\hline Imports & 1124129 & 548170 & 626279 & 731550 & 917999 & 934259 & 83,1 & -189870 \\
\hline
\end{tabular}

Source: compiled by the author 
qualitative growth due to the intensification of innovation and investment activities.

Based on the principles of system-integrated approach, the theoretical configuration of the mechanism of innovation and investment development of the livestock industry is formed, the feature of which is its focus on the formation of demand for innovation activity by enterprises producing animal products and selection of innovation and investment projects. The components of the mechanism for the implementation of innovation and investment development of animal husbandry are structured in the following three blocks: 1) the formation of demand for investment in technical and technological modernization; 2) development of variability of measures aimed at intensifying innovation and investment activities; 3 ) implementation of the developed measures.

Strategic and tactical tasks of technical and technological renewal of livestock production to increase the income of the industry can be solved on the basis of practical implementation of a set of measures in the following areas: creation of information technology platform for incorporation of innovations in livestock production; stimulation of intersectoral cooperation in the implementation of innovation and investment projects; introduction of effective mechanisms of technology transfer; establishment of consulting centers for coordination of innovation and investment activities of livestock producers; incorporation of program methods into the system of state regulation of the development of domestic animal husbandry; digitalization and reengineering of business processes, increasing the volume of direct financial support for the spread of innovative processes in animal husbandry and revision of procedures for its provision.

A promising direction of implementation of strategic imperatives of state regulation of innovation and investment development of the livestock industry is the widespread introduction into its practice of a proactive approach and programming, which determined the variability of methods and tools of state influence to achieve goals and objectives of such development. The combination of these approaches will allow to direct the limited financial capabilities of the state in innovation and investment projects on the criteria of economic rationality, profitability, social efficiency and payback period. To determine the level of efficiency of the mechanism of innovation and investment development of animal husbandry, it is proposed to use the tools of integrated assessment of production, which allows to take into account the impact on the final results of social, economic, financial and investment components of such development. The use of the proposed approach allows to determine the points of innovation and investment growth, which must be taken into account in the process of justifying measures to intensify it.

\section{Conclusions}

The scope of innovation and investment processes of this industry directly depends on the degree of coordination of all its subjects (business structures, state, science, education and society), the level of development of the innovation environment, relevant infrastructure, propensity to innovate, system and volume state support. According to the results of the analysis of the state and development trends of the livestock industry in Ukraine, the following trends have been identified: there is a reduction in the number of animals for all species, with the exception of poultry, which increased by $3.5 \%$; milk production decreased by $9 \%$, due to a decrease in the number of cattle due to an increase in the cost of its breeding and maintenance; egg production remains stable; in the sale of animals for slaughter for all types of livestock, except poultry, there was a negative tendency to decrease. As for performance indicators, they are generally growing. The state of functioning of the livestock industry indicates the urgency of finding new markets, which is impossible without qualitative changes in production technologies.

According to the results of the study of the peculiarities of support for the development of animal husbandry in Ukraine by the state, it was found that financial instruments of state aid are limited, and their volume can not meet all the needs of the industry and form the necessary foundations for its quantitative and qualitative growth. The range of problems that accompany the provision of state support to producers of livestock products is outlined, in particular: fragmentary implementation of its individual areas; variability and complexity of conditions for receiving state subsidies; lack of effective regional support programs, etc. 
An important scientific achievement is the substantiation of strategic dominants of innovation and investment development of the livestock industry, in particular: the creation of information technology platform for the dissemination of innovations; stimulation of intersectoral cooperation in the implementation of innovation and investment projects; creation of mechanisms of technology transfer; establishment of consulting centers for coordination of innovation and investment activities of livestock producers; introduction of the program method of state regulation of state regulation; digitalization and reengineering of business processes; expanding the forms and scope of direct financial support for the spread of innovative processes in animal husbandry and improving the mechanisms for obtaining it. The scientific conceptualization of the mechanism of innovation and investment development has been carried out, the component composition of which is developed in the context of such areas as: formation of demand for innovation activity, selection of strategic alternatives for innovation and investment development and implementation of developed measures. The operation of such a mechanism will allow to solve the goals and objectives of technical and technological renewal of livestock production in order to increase industry revenues. It is proposed to evaluate the efficiency of the developed mechanism using a mathematical integrated method of analysis, which allows to characterize the impact on the final results of innovation and investment development of the livestock industry and its resource components.

\section{References:}

Cherep, A. V. (2014). "Management of innovative processes in the enterprise: modern approaches and perspectives". Formuvannia rynkovykh vidnosyn v Ukraini: zbirnyk naukovykh prats', vol. 4, pp. 43-46.

Dovhan, L. Ie., Karakai, Yu. V., \& Artemenko, L. P. (2011). Stratehichne upravlinnia [Strategic management]. Kyiv: Tsentr uchbovoi literatury.

Malik, M. Y. (2008). Do pytannia staloho rozvytku silskykh terytorii [On Sustainable Development of Rural Areas]. Ekonomika APK - Economy of agroindustrial complex, vol. 5, pp. 51-55.

Mytiai, O. V. (2014). Alternatyvni dzherela pidtrymky ta zmitsnennia ekonomichnoi bezpeky pidpryiemstv ahroprodovolchoi sfery [Alternative sources of support and strengthening of economic safety of enterprises in the agro-food sector]. Naukovyi visnyk Khersonskoho derzhavnoho universytetu. Seriia: "Ekonomichni nauky" - Scientific Herald of Kherson State University. Series: "Economic Sciences", vol. 9-1, part 1, pp. 57-60.

Karasova, N. A. (2008). Renovatsiya osnovnykh zasobiv sil's'kohospodars'kykh pidpryyemstv $\mathrm{v}$ umovakh lizynhu [Renovation of fixed assets of agricultural enterprises under leasing conditions]. Economics: problems of theory and practice, vol. 244, pp. 539-546.

Shcherbata, M. Iu. (2014). Upravlinnia oborotnymy aktyvamy molokopererobnykh pidpryiemstv APV [Management of working assets of dairy processing enterprises]. Biznes-navihator - Business Navigator, vol. 1, pp. 155-159. 